Men and Animals in Benin Art

Paula Ben-Amos

Man, New Series, Vol. 11, No. 2. (Jun., 1976), pp. 243-252.

Stable URL:

http://links.jstor.org/sici?sici=0025-1496\%28197606\%292\%3A11\%3A2\%3C243\%3AMAAIBA\%3E2.0.CO\%3B2-C

Man is currently published by Royal Anthropological Institute of Great Britain and Ireland.

Your use of the JSTOR archive indicates your acceptance of JSTOR's Terms and Conditions of Use, available at

http://www.jstor.org/about/terms.html. JSTOR's Terms and Conditions of Use provides, in part, that unless you have obtained prior permission, you may not download an entire issue of a journal or multiple copies of articles, and you may use content in the JSTOR archive only for your personal, non-commercial use.

Please contact the publisher regarding any further use of this work. Publisher contact information may be obtained at http://www.jstor.org/journals/rai.html.

Each copy of any part of a JSTOR transmission must contain the same copyright notice that appears on the screen or printed page of such transmission.

JSTOR is an independent not-for-profit organization dedicated to and preserving a digital archive of scholarly journals. For more information regarding JSTOR, please contact support@jstor.org. 


\title{
MEN AND ANIMALS IN BENIN ART
}

\author{
Paula Ben-Amos \\ Temple University, Philadelphia
}

This article explores the role of animals in Benin thought and art. Animals are metaphors which define essential humanity through the establishment of its outer limits-the nonhuman or uncivilised and the more-than-human or supernatural. In particular artistic contexts, specific animals are utilised to express notions of order and harmony in the universe and the power-both political and supernatural-that obtains when this order is violated.

\section{I}

\section{Introduction: the ideal relationship}

The art of the Benin Kingdom, in present-day Bendel State, Nigeria, became known to the Western world when thousands of pieces were brought out by a British army expedition in I897. The corpus of Benin art consists of a wide variety of objects in ivory, wood, iron, terracotta, leather, and of course, brass. These famous brasses (usually termed 'bronzes') have been analysed on stylistic grounds by William Fagg (1963) and Philip Dark (1973), and have been assigned to several historical periods, dating from the fourteenth century to the present.

Animal representations are found on all major types of Benin sculpture-from royal ancestral altar pieces to village mud shrines. The frequency of their representation and the variety of contexts in which they are found are indicative of their significance in Benin art and thought. ${ }^{\mathrm{I}}$

Discussing animals in general, James Fernandez (1974: 120-I) has recently suggested that they constitute a 'primordial metaphor' through which men come to define their own humanity. ${ }^{2}$ In his words: 'those we domesticate have domesticated us and those we have not domesticated are still useful in measuring the achievement or excesses of our domestication' (1972: 4I). In the case of Benin, as we shall see, the concept of the nature and defining characteristics of animals functions to establish the outer limits of humanity, that is, the non-human or uncivilised as well as the more-than-human or supernatural.

Implicit in the contrast between animality and humanity is a notion of underlying order in the universe. In Benin cosmology, all beings are assigned to specific spheres or domains, some of which are geographical (such as the dry land and great waters), others are existential (the spirit world and the world of daily life) or temporal (day and night). Within each of these domains relationships are hierarchical and orderly. The social structure parallels the human division into noble and commoner classes, and specific roles are recognised such as king, warrior, magician, and even spy. Order within each realm is maintained by each member's acceptance of his station in life and by his following the laws of his intrinsic nature. In the Benin adage, 'Birds do not fly the sky at large but everyone goes its way' (Ahianmwen itin ukhunmwun vbee domwan d'uro ere olele).

$\operatorname{Man}$ (N.S.) II, 243-252. 
The ontological distinction between men and animals is expressed symbolically in art, myth, and ritual in the contrast between their respective spheres of activity -the home (the social world of the village) versus the bush (the wild forest areas). A myth related to me by Imaguomwanrhuo Idemudia, a priestess in a healing cult, explains the nature and significance of this distinction:

Both bush and home animals were created by Osanobua, the High God. The difference between them was caused by a rift between King of the Bush and King of the Home. King of the Home was then Ogiso (ruler of the mythical first dynasty of Benin kings) and King of the Bush was Leopard. When God created them, King of the Bush had more animals than King of the Home, and those of King of the Bush were more wild than domestic animals. Ogiso was at that time claiming supremacy, whereas Leopard had more followers. So Leopard said to him, 'If you claim supremacy, let us test our powers and see which one God has gifted with more.' King of the Home left and reported to Osanobua the attitude of King of the Bush towards him. He was advised by God not to entertain any fear. But King of the Home reported to God that the trouble would result in a fight between them, and that he had few children, whereas King of the Bush had plentiful ones. If fighting breaks out, he will not be able to withstand King of the Bush. If the antelope alone is sent from the bush to wage war against his subjects, they cannot withstand it. How much more if all the wild beasts of the bush are sent! God replied, 'Do not entertain any fear. I am the creator of all animals. I created the animals of the bush so that they can be killed and consumed by man and the spirit world.' Osanobua asked King of the Home, 'What is the date of your fight?' King of the Home replied, 'The next seven days to come.' On the seventh day, God made a ritual pot and put palm fronds in it. Then God advised King of the Home, 'As soon as the fighting begins, get your wiseman to carry this pot and to sprinkle its water with the palm fronds on King of the Bush's soldiers.' As soon as the fighting started and it was sprinkled, all the beasts in the bush started transforming into human beings. Those transformed into humans joined King of the Home's troops and the remaining ones ran into the bush along with Leopard. This is why we have an adage that whenever someone behaves abnormally, we ask him, 'Why are you behaving like a bush animal?' It is from that period that the word 'beast' (aranmwen-oha) applied to humans started. Then after the war was over, King of the Home went to God to report and to thank him for the power given him. Then God took charms and cursed bush animals that henceforth they would never come and wage war with domestic ones. God gave authority to man that whenever he finds bush animals he can kill them.

This myth reflects the basic principles underlying the ideal relationship between humans and animals and alludes to the consequences of their violation. Boundaries are drawn up and their maintenance divinely sanctioned. As Imaguomwanrhuo Idemudia makes clear in her exegesis, the distinction between the realms of men and animals is a symbolic expression of the dichotomy between wild and civilised, nature and culture:

Any shameless person is a bush animal. He does not have the blood of ordinary people but that of a transformed beast. Some families, right from the ancestors, look different from other people, are not progressing, do not behave well. (In the Bini adage) we describe them as 'people who gobble up kola nuts without peeling and dividing them' (ovbi-osa n'ukumanyan n'o rievbee rikpakpa).

The kola nut is the symbol par excellence of civilisation, of supernaturally sanctioned sociability. Householders generally welcome guests by offering them kola nuts. After an invocation, the nut is broken into segments and distributed according to relative seniority. Paralleling this domestic ritual is the Salutations 
ceremony (Otue) which opens Igue, the major yearly ritual of Benin divine kingship.

Enthroned before his father's altar, the Oba receives his chiefs as, rank by rank, from the lowest to the highest, they come to salute him. Each group kneels in homage ... Then, starting from the senior chiefs, the Oba sends them kola nuts and wine, in descending order of seniority.... At Otue the Oba is the host and the kingdom his household (Bradbury 1959: 187-8).

The Salutations ceremony, as Bradbury points out, functions to demonstrate publicly the relative rank of office holders. But it is also a pledge of support. By accepting the kola nut, the recipient is accepting his position within the hierarchy and demonstrating his recognition of legitimate authority.

Kola nuts are usually offered to guests on a wooden or china plate, or somewhat more prosaically, with the bare hands. Chiefs and wealthy men, however, may purchase carved wooden containers in order to underscore their wealth and provide an aesthetic dimension to the rite. These boxes (orievbee) are mainly rectangular with geometric or figurative designs, although a few are circular or in the form of an animal or fish. Since kola nut boxes are status markers, a number of animals appear on them which, as we shall see later, are symbols of rank: the leopard, elephant, snake, and crocodile. However, other frequently represented animalsthe cow, antelope, fish (particularly mudfish), and pangolin-do not fulfil this function, and their depiction on these boxes requires explanation. ${ }^{3}$

The carved box (pl. $\mathrm{s}$ a) represents either a cow or an antelope; my informants disagreed strongly as to its identification. (Since most of Benin art was removed in I 897 by the British army expedition, and objects such as these may never have been seen or created by contemporary chiefs and artists, identification of specific species is often difficult.) In this particular context, however, the cow and the antelope are equally effective artistic symbols through their exemplification of traits of physical attractiveness and social docility. Both are considered beautiful animals, the cow for its rich, fat body and the antelope for its smooth gait and curving horns. 4 These qualities, plus their gentle natures and desirability as food, make them favourite sacrificial offerings.

The mudfish is the freshest, most robust and most delicious of all fish and is considered very attractive and desirable. It represents prosperity, peace, well-being and fertility through its association with the water, the realm of the sea god, Olokun. ${ }^{5}$ It is one of the most popular sacrifices in Benin.

The pangolin is considered very 'shy' or 'shameful' because it rolls itself up into a ball when attacked. While viewed as an extremely ugly animal en toto, its skin is thought to be beautiful and, before the importation of European red flannel, it was used in chiefly robes. Even today the red ceremonial outfit of chiefs is called 'pangolin skin' (ikpakp' ekhui). ${ }^{6}$

These animals depicted on kola nut boxes-the mudfish, antelope or cow, and the pangolin-all share certain characteristics: accessibility, docility, and vulnerability. All domestic creatures (by definition) and certain wild ones, such as the antelope, are easily caught by man, and more especially, they do not attack or fight back. Moreover, they all can be killed without restriction and consumedthey are freely for man's use. The fact that they are represented in the form of a container expresses their complete and utter utility to man. 
These characteristics are shared with other animals and birds appearing in art as metonymic references to sacrifice: the goat, ram, chicken, and (again) cow. ${ }^{7}$ Free standing carved or cast fowl and ram's heads are placed on ancestral altars as decoration and commemoration of the deceased (pl. $\mathrm{x} b$ ), while goats, cows, and rams, both as a whole and in the form of skulls, are depicted in relief on altars of the hand ${ }^{8}$ and bronze plaques. In both cases the reference is to the wealth involved in making substantial sacrifices. While the religious meaning of sacrifice obviously differs from the previously discussed rituals, the social behaviour clearly parallels the kola nut ceremonial: the meat of the slaughtered animals is carefully distributed among the participants according to social status and is then consumed by all present in a feast of solidarity.

Towards all these animals man is hostile, aggressive, and devouring. In so doing, he is expressing his domination. In the ideal order of things-and this is the second major assertion in the myth-man dominates animals as his god-given right. This domination is expressed in his licence to take their lives with impunity. The right to kill is the defining characteristic of leadership. As Bradbury (1967: 33) points out, 'One of the most important meanings of human sacrifice, for which Benin becomes notorious, lay in its capacity to demonstrate the sole right of the Oba to take human life.' Although no ordinary man may take another's life, all men may kill domestic and game animals. Thus, through their docility, accessibility, and submissiveness, the mudfish, chicken, antelope, and cow represent the ideal order, the submission to the dominance of man.

But there exists a set of animals which reverse this relationship, which hunt man and consume his flesh. These are called by the Bini aranmwen dan or kho, dangerous or hostile animals. By their capacity to kill they make humans accessible and vulnerable. This reversal of the dominance order takes place in two contexts: hostility within the framework of order and control is a metaphor for leadership, while hostility which violates order is an embodiment of extraordinary power.

\section{Danger and authority}

Certain animals, birds, and reptiles considered dangerous by the Bini are symbols of legitimate authority and are used in contexts supportive of political power; these are the leopard, elephant, python, crocodile, and vulturine fish eagle. Their representations appear on a variety of objects, cast in brass, sewn on leather, and carved in wood and ivory, which function in the commemoration of royal achievements and the aesthetic enhancement of status.

The most important of these, the leopard, is designated the King of the Bush, as mentioned earlier, and thus stands in artistic and mythological contexts as the counterpart of the Oba of Benin, the King of the Home. Although considered beautiful, the leopard's major quality in the Bini view is its vicious and predatory nature, as reflected in its praise name, ekpelobo, 'quick in catching'. Often depicted on the prowl, with its tail curved over its back, or pouncing upon a passive victim, the leopard is the essence of aggression in graceful motion (pl. 2a)..$^{9}$ According to a myth related by Aikaronehiomwan Isibo, a diviner/healer, the leopard was chosen for kingship over the animals by the High God not only because of its fierce power and colourful regalia, that is, its beautiful skin, but also for its good 
nature and capacity to convene and direct an orderly, peaceful meeting of animals. Thus, the predatory nature and ferocity of the leopard are balanced by qualities of restraint and moderation in leadership.

Because of its size and power the elephant is considered a lord (ogie) among the animals-but specifically not a king $(o b a)$. In fact, many folktales deal with the rivalry between the leopard and the elephant for seniority, and in their historical traditions, Bini associate powerful rebel chiefs with the elephant. ${ }^{10}$ When an important man dies in Benin it is said that 'an elephant has fallen out of society'.

Representations of the elephant appear on such chiefly accessories as leather fans, hip masks, and shrines of the hand. The tusk of the elephant was especially prized for use in jewellery and as an object of decoration in its own right. As the Chief of the Brasscasters' guild explained, 'Its teeth are expensive and so elephant's name is very high.'

The python and the crocodile are both associated with the realm of Olokun, lord of the great waters. The python in particular is considered the 'playmate' and messenger of Olokun, sent to warn neglectful devotees to change their ways. The python is considered the king of the snakes and is admired for its great stature, beautiful coloration, and crushing power. Prior to the destruction of Benin City by the British army expedition in I 897 , a large brass casting of a python decorated the frontal turret of the palace, ${ }^{\text {II }}$ emphasising the correspondence between King of the Dry Land (the Oba) and King of the Sea (Olokun). The crocodile shares the power but not the beauty of the python. For its ferocity and tenaciousness, it is considered to be the policeman of the water, sent by Olokun to punish evildoers by overturning their canoes. Representations on brass plaques indicate that warriors once wore images of crocodile heads, probably as amulets for protection. ${ }^{12}$

The vulturine fish eagle is the king of the day birds. Like the leopard and crocodile, it has a vicious and predatory nature. Its beautiful white feather is worn by chiefs as a symbol of respected old age and proper chieftaincy and it is represented-in fact, the only artistic depiction of the fish eagle-on the wooden commemorative heads (uhunmwun-elao) placed on chiefly ancestral shrines. ${ }^{13}$

The leopard, elephant, python, crocodile, and vulturine fish eagle can function as metaphors of leadership because of their taxonomic positions-they are all rulers or lords over their respective species_and because they stand in the same relationship to human society as the Oba, that is, they can take human life.

In their hostility towards humans these animals reverse the ideal relationship. Their aggression, however, is neither random nor uncontrolled, but is directed, as is that of the King himself, by forces of the supernatural world (erinmwin). The Bini believe that when leopards or crocodiles attack men they are doing so at the behest of a deity who is utilising them as an instrument of vengeance.

The ritual relationship towards these animals is quite different from that towards the passive, accessible ones. ${ }^{14}$ Leopards, elephants, and vulturine fish eagles cannot be killed freely or without ritual expiation. For instance, any hunter who accidentally kills a leopard must report to the king, swearing seven times that he has killed the leopard of the bush, not the leopard of the home. In olden days, special guilds used to exist to hunt elephants, leopards, and fish eagles, and in the latter two cases, to bring them back alive and maintain them in captivity. 
None of these five creatures can be utilised for sacrifice except under highly restricted conditions. For example, the crocodile is rarely sacrificed because, as one informant succinctly claimed, 'Before you've even thought of sacrificing it, you've had it!' The leopard and the elephant may only be sacrificed by the King (pl. $2 b$ ). At the yearly Igue ceremony, reaffirming his divinity, the King sacrifices a leopard to his own head, the locus of mystical power. His possession of live and tamed leopards, with whom he used to parade in the streets, and ultimately, his taking of the life of the leopard to strengthen his own powers, symbolises for the Bini the ultimate domination of King of the Home over King of the Bush.

\section{Hostility and abnormal power}

In the second category there are certain animals which are dangerous because their hostility to man is derived from a breakdown of boundaries between realms and a violation of the ideal order-these are transformed animals, wild animals of the bush and night, associated with witchcraft and power beyond the normal. ${ }^{15}$ The capacity to transform into a wild night creature represents the pinnacle of supernatural power obtainable by man. This relationship between men and animals is qualitatively different from those previously discussed, for the dissolution of boundaries creates a new ontological status of paradoxical duality. In transforming, the human becomes both man and animal: the identity between them is no longer metaphoric but substantial. ${ }^{16}$

Two categories of humans achieve this abnormal power: the witch (azen) and the diviner/healer $(o b o)$. The Bini believe that witches operate through transformation. Since, like all other realms, the witches' society is hierarchically organised, with a ruler (Obason, 'king of the night'), a council of elders (eniwaren ason, 'elders of the night'), and commoners (azen, 'witches'), the particular animal or bird in to which they transform depends on their status and specific duties. For instance, the lord of the witches has the right to become a grey heron, king of the night birds, while commoners can transform into owls, which are only messengers. At night, witches send out their life force (orhion) in the guise of one of these hostile birds or animals and they transform the life force of their intended victim into a passive animal, a goat or antelope, which they then devour. 'In the marketplace of the witches, humans are the goats.' As Beidelman points out:

A witch's behavior is inverted physically, socially and morally. He works at night ... and he travels ... without the impediments experienced by ordinary people ... He treats all humans like non-humans, killing and eating people as though they were animals (1963:67).

The obo differs from the witch primarily in that he is not morally inverted. Yet, to accomplish his goals, he too must cross the boundaries between village and bush, day and night, human and animal. There are many different types and ranks of $e b o$ (plural of $o b o$ ) specialising variously in divination, curing, administering ordeals, or fighting witches. ${ }^{17}$ The specialists in divination and curing deal with the inverted world of the witches indirectly, through knowledge of the signs of their impact and of the medicines and devices to ward them off. But the one who combats witches must take on the attributes of their realm. Dressed in black, he goes 
out at night to the crossroads, the meeting place of this world and the spirit world (agbon vb'erinmwin), where he negotiates with witches in order to ransom the captured life force of their victims.

Certain $e b o$ have reached full ritual status (ebo n'osegberhan); they have abnormal powers and special medicines which enable them to fly through the air, disappear when in danger, and especially to transform into animals. According to Aikaronehiomwan Isibo, himself an obo:

There is an adage in Benin that an obo who is not able to transform himself into a cow or leopard is not a real obo. Once an obo has reached the age to be able to do this, he is beyond sexual relations. He has had all his children and won't eat food cooked by a woman again. ${ }^{18}$

By going beyond normal human relations, and beyond normal human capacities, into the realms of the bush and the night, the obo now stands in relation to human society in the same position as the witch, although he represents the positive side of the coin. He shares the same powers, but utilises them for good.

One locus of the obo's power is his medicine staff (osun ematon), a wrought iron $\operatorname{rod}(\mathrm{pl} .3 a, 3 b)$ surmounted by a bird and decorated with figures of other birds, animals, reptiles, and a variety of objects of ritual and daily usage (ceremonial swords, hoes, etc.) The use of iron links the obo to the warrior, hunter, and craftsman, all of whom have Ogun as patron deity. Ogun is the mystical force inherent in metal and associated with blood, flames, vengeful anger, and warfare. ${ }^{19}$ While craftsmen attempt through periodic sacrifice to keep the iron of their tools 'cool', that is, to tame its force for civilising purposes, the ebo exploit its power to go beyond civilisation and control. It is their means of transformation.

The imagery of the staff provides a further link between the obo and the warrior, the destructive force of Ogun and the transformational capacities of the god of medicine, Osun (the power inherent in leaves and herbs). In addition to the ceremonial weaponry usually represented, there also appears the image of the bird ahianwen-oro, 20 a reference to the victorious battle of Oba Esigie over the Attah of Idah in the early sixteenth century. (A casting of this bird is carried by chiefs at the yearly ceremony commemorating this victory). The staff itself is seen as representing flames shooting upward. Its praise name in Bini is osun nigiogio, osun meaning the power inherent in medicines and giogiogio meaning burning up with heat. Thus, Aikaronehiomwan Isibo claims, 'When a diviner/healer goes to battle he cannot be caught because he will turn into an osun nigiogio and spark fire and nobody can come near.' In the olden days, an obo actually used to accompany soldiers to the war to insure success against their enemies. The idiom to describe a powerful obo-and indeed any magically powerful individual-is to claim that he cannot be caught in battle. When faced with an invincible foe, he will transform into an animal or disappear. The battlefield is the ultimate testing ground of a man's control over his own life. If the highest degree of political power is the right to kill, the pinnacle of magical strength is to be invulnerable, to be in complete control of your own destiny-truly a power beyond the normal.

The animals and birds represented on the medicine staff are mainly the hostile ones of transformation. Each appears on the staff in accordance with its role in the night world. At the top of most osun ematon is the dominating figure of a bird, either astride an animal or surrounded by a secondary group of birds. Several types 
of birds may be depicted, but the most important is the grey heron (akala), the king of the night birds. ${ }^{21}$ As the supreme night creature, it is, in the words of Osarenren Omoregie:

the means of mobility for Obason, the king of the night. A wizard must reach a first class rank of Lord of the Witches before he can transform into a grey heron and then he can attend meetings at far distances. If the chief wizard wants to hold a meeting in London this night, transformation into a grey heron will dignify him and he will be respected.

The grey heron is viewed as a vicious, predatory creature with a long sharp beak and a huge head. It is used by powerful men not only as a means of mobility, but to strike terror and cause disease. Other night birds are represented in subordinate positions on the staff, such as the owl, the spy of the night people, or the senegal coucal, their timekeeper. All night birds are warriors with sharp piercing beaks.

Along the stem of the iron staff are frequently found images of the chameleon. It is one of the main animals associated with the diviner/healer because it symbolises his greatest power: transformation. Von Sydow (1938: 59) quotes the Oba as saying: 'The chameleon figure on the Osun rod symbolizes how the world is changed by the magic power of the medicine man just as the chameleon can change the color of its skin.' In the night world, the chameleon is a spy. As Izevbiohen Idemudia, an obo, explained:

The chameleon is the camera of the night people; that is why it changes colour all the time. The skin is like camera film. If an obo transforms into a chameleon whatever it sees at night it pictures and reports back to the grey heron, Lord of the Witches.

The chameleon is considered a symbol of wisdom in a double sense, that is, the wisdom acquired in old age (indeed, the gait of the chameleon is compared with that of an old man), but also the cleverness associated with the ability to change to meet all situations. Unscrupulous and tricky individuals are nicknamed 'chameleon.'

Along the sides of the iron staff, often shooting upwards like flames themselves, are representations of snakes. The snakes aka ovbivbie, and iviekpo ${ }^{22}$ are the most dangerous because they are the warriors of the night people sent by Osun, the god of medicine, to kill offenders.

Man's passivity towards these animals is clearly established in his ritual relationship towards them. All hostile animals are taboo (awua), forbidden for consumption. It is similarly forbidden to kill any of them, and only the most powerful native doctors dare claim to use one for sacrifice.

All the hostile animals and birds of the night share one characteristic: they violate Bini canons of aesthetics. Some are disproportionate: the grey heron and the snake aka are believed to have huge, clumsy heads in relation to their bodies, a trait considered particularly ugly in Benin. Others are anomalies in Mary Douglas's terms (1957; 1966), that is, they combine characteristics cutting across taxonomic categories, such as lizards, bats, and frogs. The snake ovbivbie, for instance, is believed to have the head of a cock and to crow as it spits. Both the submissive and the kingly animals that appear in Benin art, such as the cow or the leopard, are considered beautiful (mose). They are visual statements about proper order. In contrast, witches are inversions of the proper order-they are monsters. And, in their ugliness, the animals into which they change are visual statements about moral aberration. ${ }^{23}$ 
NOTES

Fieldwork was carried out in Benin City in 1973 with the assistance of Osarenren Omoregie of the Mid-West Arts Council Sub-Committee on Research and was supported by grants from the American Philosophical Society and the Social Science Research Council. Philip Dark supplied information from his files on Benin art and my husband, Dan Ben-Amos, offered many helpful suggestions.

I In this article I will deal with only one aspect of the complex symbolism of animals in Benin; that is, the way in which animals constitute images of order and 'potent disorder' (Douglas I966) in the universe.

2 The notion of animality as a metaphor for defining humanity has been dealt with on a general level by Lévi-Strauss (I963; I966) and with regard to specific cultures by Buxton (1968), Douglas (I957), Geertz (1972), and, most recently, Willis (I974).

3 For illustrations of kola nut boxes with representations of a cow/antelope see Forman and Dark (1960: plate I3) and Pitt Rivers (I900: XLIV-336). For the pangolin see Dark (I962: XX-47) and Coon and Plass (I957: 36), and for the mudfish see von Luschan (1919: pl. II7) and Pitt Rivers (1900: XLVII-372-3).

4 Long curved horns are considered particularly beautiful in Bini aesthetic judgments of animals and a special praise name, azigho, is applied to animals exhibiting this trait. One of the masks most commonly used in the Ekpo cult healing rituals is called azigho (see Lopasic 1965).

5 Olokun is the most widely worshipped deity in the Bini pantheon and is considered the bringer of health, wealth, and fertility. See Ben-Amos (1973) for a discussion of the artistic symbolism of the Olokun cult.

6 In this context the pangolin contains a more explicit chiefly reference than the cow/ antelope or mudfish. Its association with chiefs, particularly as they stand in political opposition to the king, is expressed in the belief that 'the pangolin is the only animal the leopard cannot kill' (Chief Eghobamien 1973 : personal communication). It is interesting to note that the pangolin is not considered an anomaly, as in the case of the Lele described by Douglas (1957).

7 Illustrations of freestanding sacrificial animals can be found as follows: brass cocks in von Luschan (1919: pl. 76) and Forman and Dark (1960: pl. 85), wooden hen in Dark (1962: XLII-83), wooden rams' heads in Fagg (1963: pls I03, ro5).

8 The altar of the hand is dedicated to the power of individual achievement in the search for material success. For information and illustrations see Bradbury (I96I).

9 A similar view of the visual and behavioural qualities of the leopard is found among the Ejagham of the Cross Rivers. See Thompson (1974: 184-7).

10 The elephant is particularly associated with the Iyase n'Ode, a Prime Minister said to have rebelled against $\mathrm{Oba}$ Akenzua I in the I8th century (Egharevba I960: 40). Illustrations of carved tusks can be seen in Forman and Dark (I960: pls 7I-2) and elephants represented in appliqué on a leather fan can be seen in Dark (I962: II-92).

II Van Nyendael, who visited Benin in I7OI, describes a copper snake on the turret of the palace (1705: 534). A representation of what the palace probably looked like before it was destroyed in r897 can be seen in von Luschan (1919: pl. 90).

12 A plaque depicting warriors with crocodile head ornaments is illustrated in Dark (1962: I-250). von Luschan (I9I9: pl. 46) has examples of a number of plaques with crocodile images.

13 For an illustration of a wooden commemorative head see Dark (1962: XXIX-129).

14 In Benin, there is a relationship between dietary prohibitions and animal classification systems which is similar to that found by M. Douglas (I966:4I-75) in the Old Testament and by S. J. Tambiah (1969) in Thailand. The domestic and passive animals may be killed and eaten without restriction, but the hostile ones, particularly those associated with nighttime and witchcraft, are tabooed (awua).

15 While most hostile animals are found in the bush or rivers, there are two domestic onesthe dog and the cat-which are potentially dangerous because they can be 'polluted' by witches and turned against men. Both of these animals are believed to possess inherently aggressive natures which have been modified through long contact with man.

16 The terminology of 'metaphoric' versus 'substantial' identity is based on Finnegan and Horton (I974: 43). Firth (I966) has argued that men-animal equations are a type of metaphor, but here I agree with Buxton (1968) that it is a question of 'real identity' not 'a way of representing ideas'. The creation of metaphor is impossible without the presupposition of boundaries between categories.

17 For a description of the different types of ebo see Melzian (1937: 157 ).

18 The choice of leopard and cow as the pinnacles of transformation is based on their positions as supreme bush and home animal respectively. 
19 Bini beliefs about Ogun are closely related to those of the Yoruba described by Thompson (1971: Ch $7 / 1-7 / 2$ ).

${ }^{20}$ Based on information supplied by the Ministry of Agriculture and Natural Resources, Benin City, the bird ahianmwen-oro may tentatively be identified as a type of kingfisher. It is represented on the above-mentioned palace turret (see note II).

${ }^{21}$ The symbolism of the gathering of the birds in Yoruba art is discussed by Thompson (1970) and much of the imagery is paralleled in Benin. A medicine staff with a representation of the grey heron, akala, can be seen in von Luschan (1919: pl. 109).

22 According to Melzian, aka is a grass-snake (I937: 5) and ovbivbie is a black mamba (1937: I53). He has no attribution for iviekpo.

${ }_{23}$ Rebecca Agheyisi (1973: personal communication) has indicated that the Bini word for ugly, khorhion, is a compound of kho, hostile, and orhion, life force-a particularly appropriate combination of the aesthetic and the moral.

\section{REFEREN CBS}

Beidelman, T. O. 1963. Witchcraft in Ukaguru. In Witchcraft and sorcery in East Africa (eds) J. Middleton \& E. H. Winter. New York: Frederick A. Praeger.

Ben-Amos, P. 1973. Symbolism in Olokun mud art. Afr. Arts 6, 4, 28-31, 95.

Bradbury, R. E. 1959. Divine kingship in Benin. Nigeria Mag. 62, I86-207. I96I. Ezomo's ikegobo and the Benin cult of the hand. Man 6I, I29-38.

1967. The kingdom of Benin. In West African kingdoms in the nineteenth century (eds) D. Forde \& P. M. Kaberry. London: Oxford Univ. Press.

Buxton, J. 1968. Animal identity and human peril; some Mandari images. Man (N.S.) 3, 35-49.

Coon, C. S. \& M. Plass I957. African Negro sculpture. Univ. Mus. Bull. 21, 4, 36.

Dark, P. J. C. 1962. The art of Benin. Chicago: Chicago Natural History Museum. 1973. An introduction to Benin art and technology. London: Oxford Univ. Press.

Douglas, M. I957. Animals in Lele religious thought. Africa 27, 46-58. I966. Purity and danger. London: Routledge \& Kegan Paul.

Egharevba, J. U. I960. A short history of Benin. Ibadan: Univ. Press.

Fagg, W. I963. Nigerian images. London: Lund Humphries.

Fernandez, J. 1972. Persuasions and performances: of the beast in every body ... and the metaphors of everyman. Daedalus, winter, 39-60.

- 1974. The mission of metaphor in expressive culture. Curr. Anthrop. 15, I19-33.

Finnegan, R. \& R. Horton (eds) I973. Modes of thought. London: Faber \& Faber.

Firth, R. 1966. Twins, birds and vegetables: problems of identification in primitive religious thought. Man (N.S.) I, I-I4.

Forman, W., B. Forman \& P. Dark 1960. Benin art. London: Batchworth.

Geertz, C. 1972. Deep play: notes on the Balinese cockfight. Daedalus winter, I-37.

Leach, E. R. 1964. Anthropological aspects of language: animal categories and verbal abuse. In New directions in the study of language (ed.) E. H. Lenneberg, Cambridge, Mass.: M.I.T. Press.

Lévi-Strauss, C. 1963. Totemism. Boston: Beacon Press. 1966. The savage mind. London: Weidenfeld \& Nicolson.

Lopasic, A. 1965. The 'Bini' pantheon seen through the masks of the 'Ekpo' cult. In Réincarnation et vie mystique en Afrique Noire: colloque de Strasbourg 16-18 mai 1963. Paris: Presses Universitaires de France.

Luschan, F. von I919. Die Altertumer von Benin. Berlin: Museum für Völkerkunde.

Melzian, H. 1937. A concise dictionary of the Bini language of Southern Nigeria. London: Kegan Paul, Trench, Trubner.

Nyendael, D. van I705. A description of Rio Formosa, or the River of Benin. In A new and accurate description of the coast of Guinea (ed.) W. Bosman. London: J. Knapton.

Pitt Rivers, A. H. L. F. 1900. Antique works of art from Benin. London: Harrison.

Sydow, E. von I938. Ancient and modern art in Benin City. Africa II, 55-62.

Tambiah, S. J. 1969. Animals are good to think and good to prohibit. Ethnology 8, 424-59.

Thompson, R. F. 1960. The sign of the divine king. Afr. Arts 3, 3, 8-17, 74-80. 197I. Black gods and kings (Occ. Pap. Mus. Lab. ethnic Arts Technol. 2). Los Angeles:

Univ. of California Press.

1974. African art in motion. Los Angeles: Univ. of California Press.

Willis, R. G. I974. Man and beast. London: Hart-Davis, MacGibbon. 


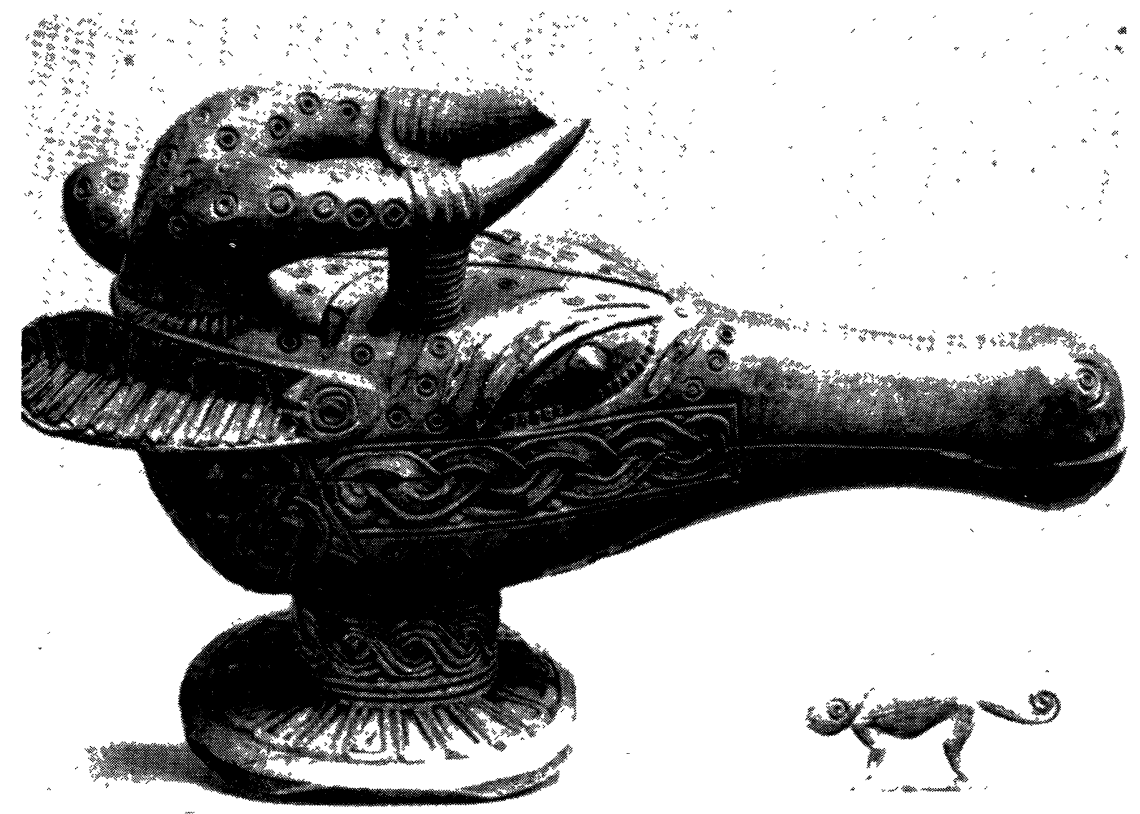

PI.ATE Ia. Ivory kola nut box representing a cow or antelope. Museum für Völkerkunde, Berlin.

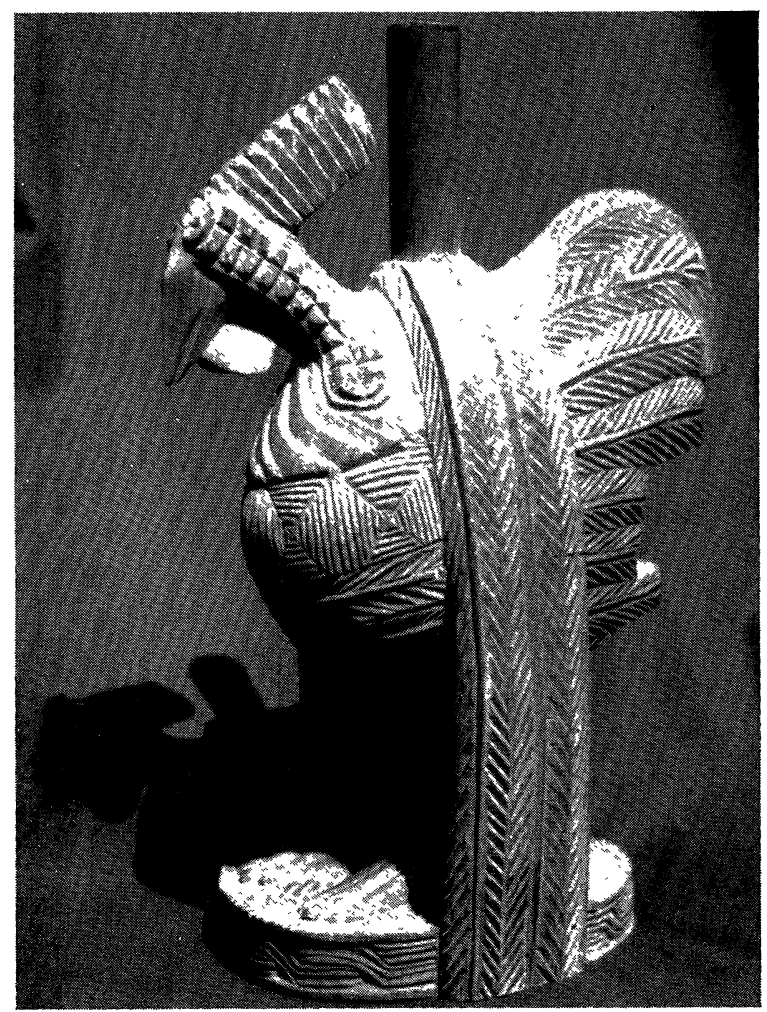

Plate I $b$. Contemporary carved wooden rooster for use on paternal ancestral shrine. Artist:

Richard Amu.

Photographer: Philip Dark. 


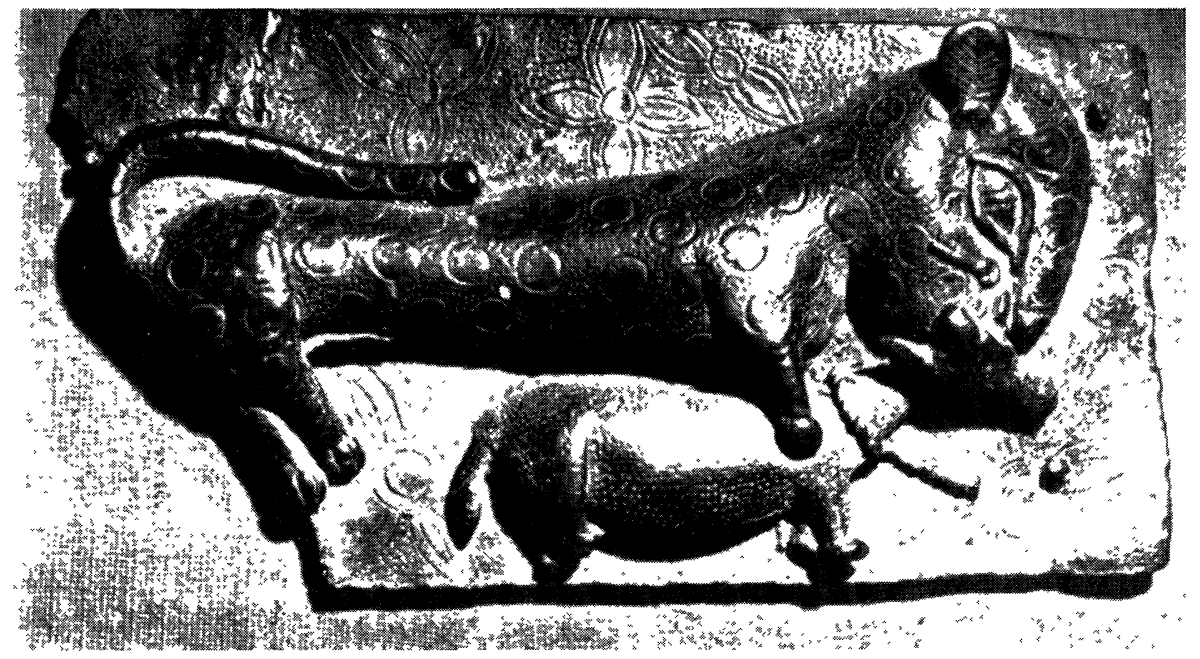

Plate 2a. Seventeenth century brass plaque of leopard pouncing on cow. British Museum.

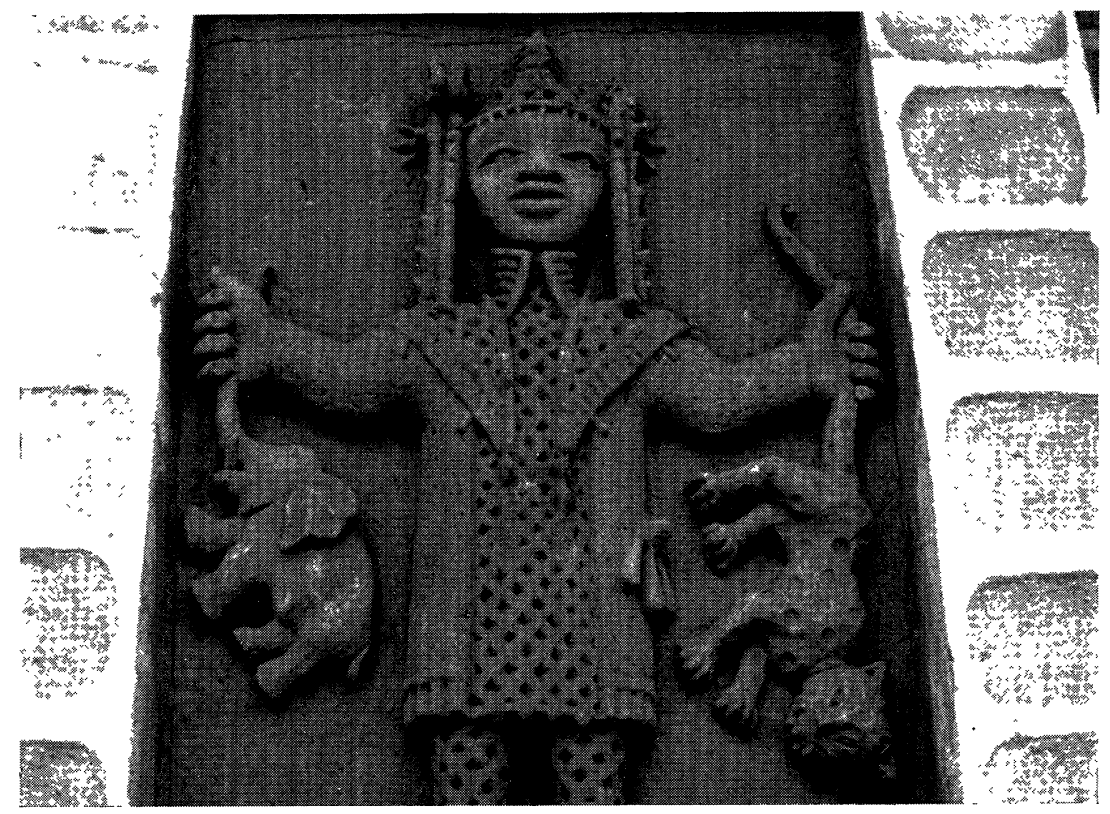

Plate $2 b$. Terracotta plaque from present palace in Benin City representing Oba Akenzua II sacrificing a leopard and an elephant. Artist: Ovia Idah. Photographer: Dan Ben-Amos. 